\title{
KETERCAPAIAN STANDAR NASIONAL PENDIDIKAN DI SEKOLAH MENENGAH ATAS
}

\section{ACHIEVEMENT OF NATIONAL EDUCATION STANDARDS IN SENIOR SECONDARY SCHOOLS}

\author{
Lia Yuliana \\ Fakultas Ilmu Pendidikan, Universitas Negeri Yogyakarta \\ Jl. Colombo No. 1 Yogyakarta \\ E-mail: lia_yuliana@uny.ac.id \\ Sabar Budi Raharjo \\ Pusat Penelitian Kebijakan Pendidikan dan Kebudayaan \\ Badan Penelitian dan Pengembangan, Kemendikbud \\ Jl. Jenderal Sudirman-Senayan-Central Jakarta \\ E-mail: raharjo2sbr@gmail.com
}

Naskah diterima tanggal: 05-08-2019 disetujui tanggal: 13-11-2019

\begin{abstract}
This study aims to determine the achievement of National Education Standards (SNP) based on accreditation data and the inhibitors in achieving National Education Standards at the high school level. A quantitative descriptive was used in this research. Data obtained from school principals, school supervisors, and education officers at the secondary education level. Data was obtained from guided discussion gathered with school principals, school supervisors, education officer representatives, and resource persons from academics and practitioners. Respondents were taken based on purposive sampling with the aim at accredited $A$ schools in urban areas. Secondary data obtained from BAN-SM, whereas the primary data obtained from the implementation of eight National Education Standards. School with A grade in accreditation is assumed could provide information on the difficulties and obstacles in the implementation of the National Education Standards. The finding showed that based on 2017 accreditation there were three educational standards with the lowest achievements namely, Educator and Educational Staff Standards (PTK), Facilities and Infrastructure Standards and Graduates Competency Standards. It was also found that there are obstacles in achieving standards at the education unit level. Standards that are difficult to achieve are Educator and Educational Staff Standards, Facilities and Infrastructure Standards, and Financing Standards. Schools accept these standards so that the fulfillment of these standards depends on the quota given by the government.
\end{abstract}

Keywords: education achievement, national education standards, senior secondary school Abstrak: Penelitian ini bertujuan untuk mengetahui capaian Standar Nasional Pendidikan berdasarkan data akreditasi dan hambatan dalam pencapaian Standar Nasional Pendidikan jenjang Sekolah Menengah Atas. Penelitian menggunakan metode deskriptif kuantitatif. Data diperoleh dari kepala sekolah, pengawas sekolah, dan cabang dinas pendidikan pada jenjang pendidikan menengah. Data diperoleh dari kegiatan diskusi terpimpin dengan kepala sekolah, pengawas sekolah, perwakilan cabang dinas, dan berdasarkan purposive sampling pada sekolah yang terakreditasi A pada daerah perkotaan. Data sekunder diperoleh dari BAN S/M. Sedangkan data primer diperoleh dari implementasi delapan Standar Nasional Pendidikan. Hasil penelitian menunjukkan bahwa pada jenjang SMA berdasarkan akreditasi 2017 ada tiga standar pendidikan yang capaiannya paling rendah yaitu Standar Pendidik 
dan Tenaga Kependidikan, Standar Sarana dan Prasarana, dan Standar Kompetensi Lulusan. Hambatan yang ditemui dalam pemenuhan standar pada tingkat satuan pendidikan yaitu terutama pada Standar Pendidik dan Tenaga Kependidikan, Standar Sarana dan Prasarana, dan Standar Pembiayaan. Dengan demikian, belum semua standar pendidikan dapat dipenuhi oleh sekolah tetapi pada sekolah swasta yang mandiri standar pendidikan dapat dicapai dengan baik.

Kata kunci : capaian pendidikan, standar nasional pendidikan, SMA

\section{PENDAHULUAN}

Pendidikan yang berkualitas bagi setiap warga negara telah dijamin dalam Undang-undang Nomor 20 Tahun 2003 tentang Sistem Pendidikan Nasional Pasal 5 ayat (1) setiap warga negara mempunyai hak yang sama untuk memperoleh pendidikan yang bermutu. Banyak pakar pendidikan yang memiliki pendapat yang berbeda mengenai pemahaman pendidikan yang bermutu namun pada dasarnya memiliki tujuan yang sama dalam pemberian layanan pendidikan bermutu kepada peserta didik. Pada era globalisasi yang memiliki dampak kemajuan pengetahuan dan teknologi semakin cepat maka dunia pendidikan dipaksa untuk menyesuaikan kemajuan supaya tidak tertinggal dengan dunia lain.

Kelayakan mutu pada satuan pendidikan mengacu pada Standar Nasional Pendidikan (SNP). SNP adalah kriteria minimal tentang sistem pendidikan di seluruh wilayah hukum Negara Kesatuan Republik Indonesia. SNP harus dijadikan acuan guna memetakan secara utuh profil kualitas sekolah/madrasah.

Terkait dengan standar nasional pendidikan telah ditetapkan melalui Peraturan Pemerintah (PP) Nomor 19 Tahun 2005 dan direvisi melalui PP Nomor 23 Tahun 2013 tentang Perubahan Atas Peraturan Pemerintah Nomor 19 Tahun 2005 tentang Standar Nasional Pendidikan. Seiring dengan perkembangan pendidikan, SNP sudah berjalan kurang lebih 13 tahun namun mutu pendidikan Indonesia posisinya masih di bawah dibandingkan dengan negara-negara serumpun. Hal ini diduga bukan karena standar nasional pendidikan yang kurang berkualitas namun pemenuhan dan implementasi standar nasional pendidikan yang belum berjalan maksimal. Hasil akreditasi dari Badan Akreditasi Nasional Sekolah/Madrasah (BAN S/M) bahwa perkembangan mutu sekolah belum menunjukkan perkembangan yang menggembirakan terhadap mutu pendidikan.

Di dalam PP Nomor 19 Tahun 2005 pasal 2 ayat 1 , lingkup SNP meliputi: 1) standar isi; 2) standar proses; 3) standar kompetensi lulusan; 4) standar pendidik dan tenaga kependidikan (PTK); 5) standar sarana dan prasarana; 6) standar pengelolaan; 7) standar pembiayaan; dan (8) standar penilaian pendidikan. Sekolah yang telah memenuhi delapan SNP mencerminkan bahwa sekolah tersebut telah memiliki mutu sesuai dengan standar yang ada. SNP yang sulit dicapai adalah standar kompetensi lulusan, ketenagaan, dan sarana dan prasarana. Variabel standar isi, ketenagaan, sarana dan prasarana, pembiayaan, pengelolaan, penilaian, mempunyai hubungan yang positif yang besarnya bervariasi terhadap variabel standar proses dan komptensi lulusan (Raharjo, 2012).

Capaian standar tersebut dibuktikan dengan hasil akreditasi dari BAN S/M. Oleh karena itu, setiap sekolah yang ada harus memiliki acuan yang sama yaitu standar nasional pendidikan. Sekolah dikatakan bermutu apabila telah memenuhi delapan SNP dengan akreditasi $A$. Dengan demikian sekolah yang bermutu yaitu sekolah yang telah melakukan proses belajar mengajar dengan acuan standar nasional pendidikan (Jaedun, 2014). Artinya standar kompetensi lulusan yang dihasilkan telah 
didukung oleh standar isi, pendidik dan tenaga kependidikan, pengelolaan, pembiayaan, penilaian, dan sarana-prasarana yang memadai.

Dari delapan SNP rata-rata capaian yang paling rendah yaitu standar pendidik dan tenaga kependidikan dan standar sarana dan prasarana. Permasalahannya yaitu kemampuan dalam pemenuhan SNP yang dilakukan oleh pemerintah pusat, pemerintah daerah, dan satuan pendidikan belum dapat meningkatkan mutu layanan pendidikan yang sesuai dengan SNP secara signifikan. Hal ini akan berdampak pada mutu lulusan peserta didik. Program pemerintah pusat ini memerlukan dukungan dari pemerintah daerah dalam implementasinya. Dalam hal ini tentu peran penting dinas pendidikan provinsi, balai dikmen, pengawas sekolah, sampai satuan pendidikan perlu melakukan sinergisitas sehingga SNP bisa tercapai dengan baik.

Permasalahan dalam kajian ini yaitu apakah satuan pendidikan dalam memberikan layanan pendidikan kepada peserta didik sudah memenuhi delapan SNP seperti dalam PP Nomor 19 Tahun 2005. Demikian juga apakah delapan SNP sudah cukup dalam mengukur mutu pendidikan kita. Fakta menunjukkan bahwa banyak faktor yang memengaruhi ketercapaian standar nasional pendidikan. Faktor-faktor tersebut antara lain: 1) Subtansi SNP belum sepenuhnya dipahami oleh kepala sekolah dan guru, 2) Pemerintah pusat dan daerah masih belum dapat memenuhi ketercapaian delapan SNP, 3) Banyaknya peraturan yang terkait dengan pengaturan delapan SNP, 4) Perubahan dan perkembangan pengetahuan dan teknologi yang cepat sehingga SNP harus menyesuaikan dengan perubahan tersebut. Permasalahan tersebut menjadi dasar dalam kajian ini karena layanan pendidikan yang bermutu harus memiliki acuan standar. Dengan ketercapaian SNP akan memberikan kontribusi yang besar bagi pemerintah dalam menciptakan kualitas sumber daya manusia yang berdaya saing dengan negara lain. Celik (2011) mengatakan bahwa sumber daya manusia sangat penting untuk memperkokoh kualitas pendidikan di sebuah negara.

Karakteristik standar kualitas dari beberapa pendapat bahwa pada prinsipnya penentuan mutu harus memiliki standar tertentu sebagai acuan yang akan dicapai (McBer, 2000). Standar yang ditentukan memberikan jaminan bagi pelanggan untuk menerima layanan yang berkualitas. Demikian juga bila dikaitkan dengan mutu sekolah maka standar yang telah ditentukan sebagai jaminan bagi peserta didik untuk menerima layanan pendidikan yang bermutu. Oleh karena itu, menurut Sallis (2002), sekolah dikategorikan bermutu apabila memiliki indikator sebagai berikut:

1. Sekolah berfokus pada pelanggan, baik pelanggan internal maupun eksternal.

2. Sekolah berfokus pada upaya untuk mencegah masalah yang muncul, dalam makna ada komitmen untuk bekerja secara benar dari awal.

3. Sekolah memiliki investasi pada sumber daya manusianya.

4. Sekolah memiliki strategi untuk mencapai kualitas, baik di tingkat pimpinan, tenaga akademik, maupun tenaga administratif.

5. Sekolah mengelola atau memperlakukan keluhan sebagai umpan balik untuk mencapai kualitas dan memposisikan kesalahan sebagai instrumen untuk berbuat benar pada peristiwa atau kejadian berikutnya.

6. Sekolah memiliki kebijakan dalam perencanaan untuk mencapai kualitas.

7. Sekolah mengupayakan proses perbaikan dengan melibatkan semua orang sesuai dengan tugas pokok, fungsi, dan tanggung jawabnya.

8. Sekolah mendorong orang yang dipandang memiliki kreativitas, mampu menciptakan kualitas, dan merangsang yang lainnya agar dapat bekerja secara berkualitas.

9. Sekolah memperjelas peran dan tanggung jawab setiap orang, termasuk kejelasan 
arah kerja secara vertikal dan horizontal.

10. Sekolah memiliki strategi dan kriteria evaluasi yang jelas.

11. Sekolah memandang atau menempatkan kualitas yang telah dicapai sebagai jalan untuk memperbaiki kualitas layanan lebih lanjut.

12. Sekolah menempatkan peningkatkan kualitas secara terus-menerus sebagai suatu keharusan.

Pendidikan nasional di Indonesia diselenggarakan melalui jalur, jenjang, dan jenis pendidikan. Jalur pendidikan adalah wahana yang dilalui peserta didik untuk mengembangkan potensi dirinya dalam suatu proses pendidikan yang sesuai dengan tujuan pendidikan (Devi, Devan, Soon, \& Han, 2012). Terdapat tiga jalur pendidikan yaitu: jalur pendidikan formal, nonformal, dan informal. Pendidikan formal adalah jalur pendidikan yang terstruktur dan berjenjang yang terdiri atas pendidikan dasar, pendidikan menengah, dan pendidikan tinggi (Kalolo, 2015). Pendidikan nonformal adalah jalur pendidikan di luar pendidikan formal yang dapat dilaksanakan secara terstruktur dan berjenjang. Pendidikan informal adalah jalur pendidikan keluarga dan lingkungan (Lee, 2010).

Dengan adanya standar nasional tersebut, arah peningkatan kualitas pendidikan Indonesia menjadi lebih jelas (Akpan \& Ita 2015). Berbagai kebijakan yang mendorong peningkatan kualitas pendidikan telah ditetapkan dan diimplementasikan dengan harapan kualitas pendidikan dapat berangsur-angsur meningkat pada tingkat yang lebih tinggi. Berkenaan dengan hal tersebut, akan dievaluasi bagaimana trend perkembangan kualitas pendidikan di Indonesia sebagai akibat adanya kebijakan-kebijakan tersebut (Alba, 2011).

Dalam mencapai tujuan pendidikan penerapan standar sangat dibutuhkan supaya mutu pendidikan dapat dikontrol. Standardisasi layanan pendidikan memberikan kepastian dalam layanan pendidikan yang bermutu. Pendidikan bermutu salah satunya adalah sistem penilaian yang juga bermutu (Scholtz, 2007).

Tujuan penelitian ini adalah untuk mengetahui: 1) capaian SNP berdasarkan data akreditasi, dan 2) hambatan dalam pencapaian SNP jenjang SMA. Manfaat penelitian ini adalah untuk memberikan masukan pada kepala sekolah, pengawas sekolah, dan dinas pendidikan mengenai hambatan-hambatan yang harus diketahui untuk menemukan solusi dalam usaha pemenuhan standar nasional pendidikan.

\section{METODE}

Kajian ini merupakan bagian dari penelitian Pusat Penelitian dan Kebijakan Pendidikan dan Kebudayan 2018 dengan topik Kajian Evaluasi Implementasi dan Restrukturisasi Standar Nasional Pendidikan. Penelitian ini menggunakan pendekatan deskriptif kuantitatif. Data kuantitatif diperoleh dari BAN S/M Tahun 2017. Analisis dengan menggunakan butir capaian akreditasi SNP. Data terkait dengan implementasi SNP diperoleh dari kepala sekolah, pengawas sekolah, dan Cabang Dinas Pendidikan Menengah pada jenjang Sekolah Menengah Atas dianalisis untuk mengetahui kendala yang dialami oleh satuan pendidikan. Responden penelitian diambil dari sekolah yang terakreditasi A atau unggulan pada daerah perkotaan dengan menggunakan instrumen angket. Sedangkan data primer dalam kajian ini diperoleh dari pendalaman pada satuan pendidikan untuk mengetahui implementasi delapan SNP. Analisis data menggunakan statistik deskriptif.

\section{HASIL DAN PEMBAHASAN}

Capaian SNP berdasarkan akreditasi BAN S/M Tahun 2017 pada jenjang SMA seperti pada Grafik 1. Rerata capaian paling rendah pada jenjang SMA yaitu Standar Pendidik dan Tenaga Kependidikan, yakni 82,2 . Paling rendah berikutnya adalah Standar Sarana dan Prasarana, yakni 82,9. Walaupun nilainya paling rendah pada jenjang SMA, keduanya telah 


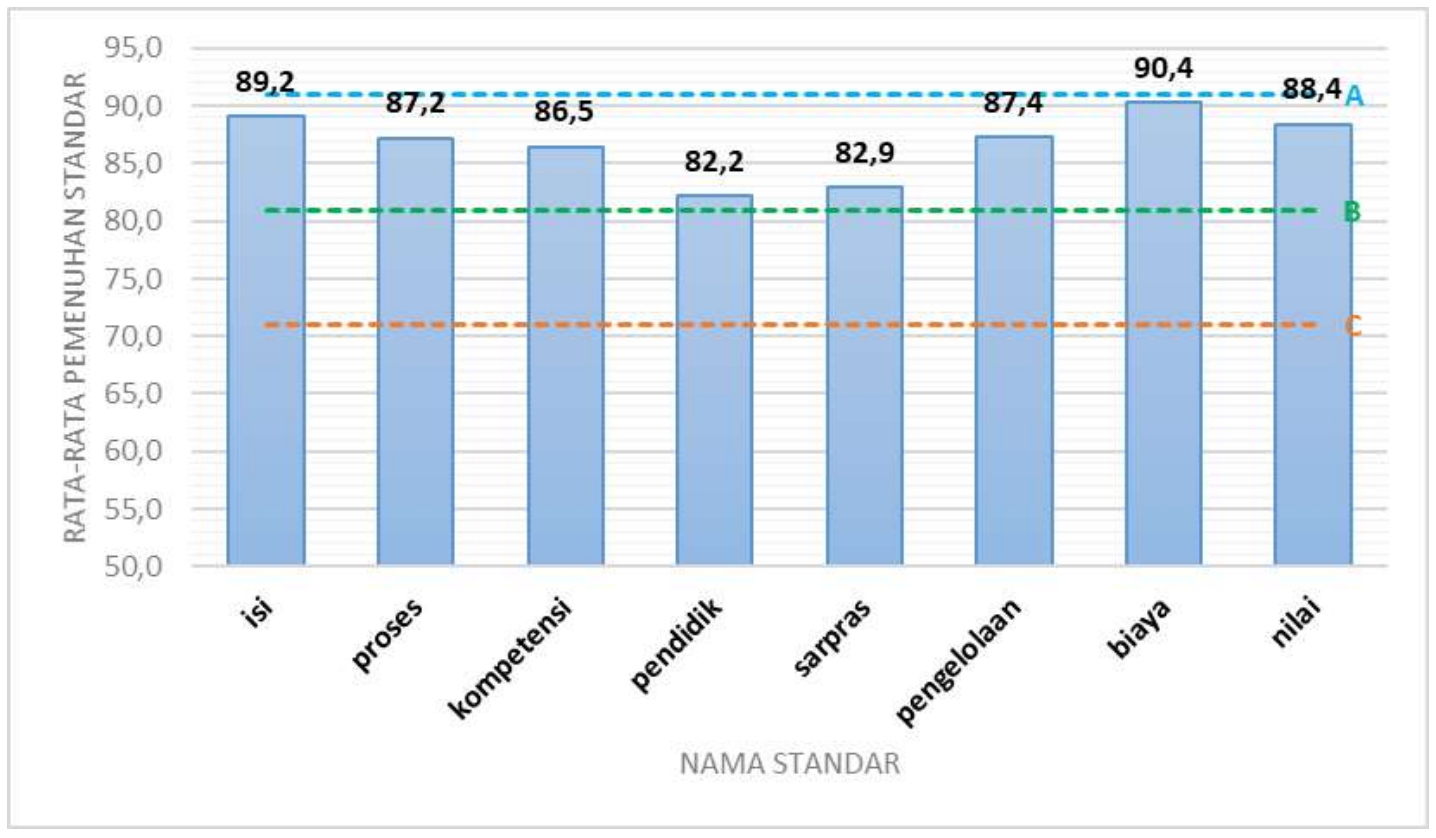

Grafik 1 Capaian Akreditasi Jenjang SMA Tahun 2017

memenuhi kriteria baik.

Pada jenjang SMA komponen standar yang rerata capaiannya memenuhi kriteria unggul adalah standar biaya. Hal ini memerlukan respon kebijakan pemerintah daerah dalam pemenuhan SNP. Berdasarkan pada analisis butir yang dilakukan terhadap jawaban dari hasil perangkat akreditasi BAN S/M Tahun 2017, yang merupakan edisi perbaikan dari versi sebelumnya, dengan kategori pilihan jawaban yaitu A, B, C, D, E. Analisis berdasarkan persentase sekolah yang memilih jawaban D atau E melebihi dari $10 \%$. Diduga butir pertanyaan tersebut sulit dipenuhi oleh sekolah. Butir jawaban perangkat akreditasi yang dirasakan sulit dipenuhi oleh sekolah dan memerlukan perhatian serius adalah sebagai berikut.

\section{Capaian pada Standar Kompetensi Lulusan dan Standar Isi, Standar proses, Standar Penilaian, Standar Pengelolaan dan Standar Pembiayaan}

Standar Kompetensi Lulusan, Standar Isi, Standar Proses, Standar Penilaian, Standar Pengelolaan, dan Standar Pembiayaan berdasarkan analisis butir tidak ada pertanyaan yang dijawab D atau $E$ yang melebihi dari $10 \%$.
Artinya, tidak ada kesulitan bagi sekolah dalam pemenuhan standar ini. Hanya Standar Proses pada butir 14, yakni penggunaan buku teks pelajaran oleh siswa dalam proses pembelajaran ada sebagian sekolah tidak bisa memenuhi. Hal ini lebih memerlukan perhatian yang serius dari pemerintah daerah maupun pemerintah pusat dalam usaha pencapaian SNP dalam bidang ini.

\section{Capaian Standar Pendidik dan Tenaga Kependidikan}

Berdasarkan pada Grafik 2, untuk Standar Pendidik dan Tenaga Kependidikan lebih dari 10\% sekolah kesulitan memenuhi yaitu butir 39, 46, 51,52 , dan 55. Hal ini dapat ditunjukkan pada butir 39: sekolah yang gurunya masih belum memiliki sertifikat pendidik kurang dari 55\%; butir 46: rasio antara guru Bimbingan Konseling (BK) dengan jumlah siswa tampak lebih kecil dengan 1:251; butir 51: sekolah memiliki jumlah tenaga administrasi masih kurang mendukung; butir 52: sekolah memiliki jumlah tenaga administrasi yang berkualifikasi memadai; butir 53: sekolah memiliki jumlah tenaga perpustakaan memenuhi syarat kualifikasi; butir 55: sekolah memiliki laboran dengan kualifikasi akademik memadai. 


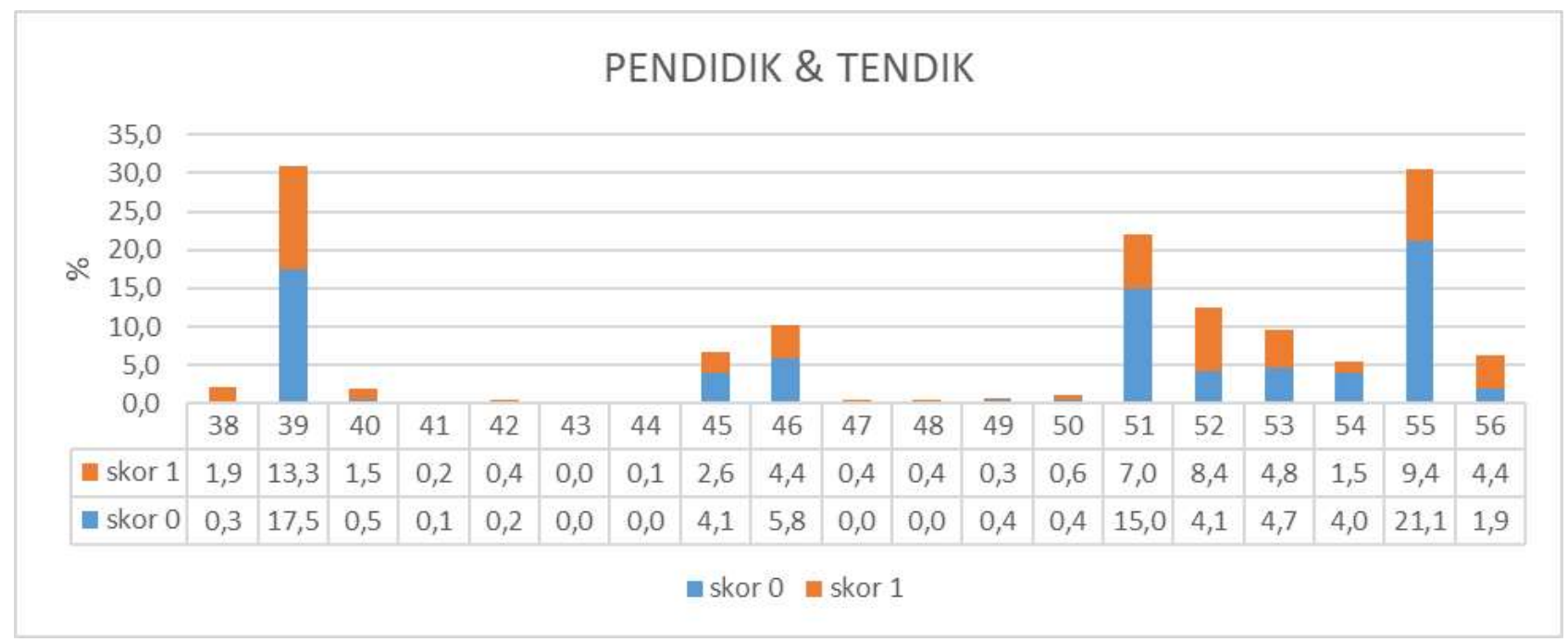

Grafik 2 Standar PTK

Hal ini menunjukkan bahwa standar PTK perlu menjadi pusat perhatian berbagai pihak. Sebagai bagian dari kegiatan pendidikan, maka keberadaan PTK sangat penting. Harus ada usaha nyata agar guru bisa 100 persen memiliki sertifikasi pendidik dan agar kualifikasi dan kompetensi tenaga kependidikan masuk dalam kategori yang memadai. Untuk hal ini pemerintah daerah harus berperan lebih banyak dan tidak menunggu kebijakan dari pusat. Untuk peningkatan kualifikasi dan kompetensi tenaga kependidikan misalnya, perlu ada insentif supaya mereka bersedia melaksanakan studi lanjut atau pelatihan-pelatihan yang produktif.

\section{Capaian Standar Sarana dan Prasarana} Berdasarkan Grafik 3, untuk standar sarana dan prasarana lebih dari $10 \%$ sekolah kesulitan memenuhi butir $67,68,69,70$, dan hampir $50 \%$ sulit memenuhi 71. Butir-butir tersebut sebagai berikut. Butir 67: sekolah yang belum memiliki ruang laboratorium biologi secara khusus; butir 68: sekolah yang belum memiliki ruang laboratorium fisika secara memadai; butir 69: sekolah yang belum memiliki ruang laboratorium kimia secara memadai; butir 70; sekolah yang

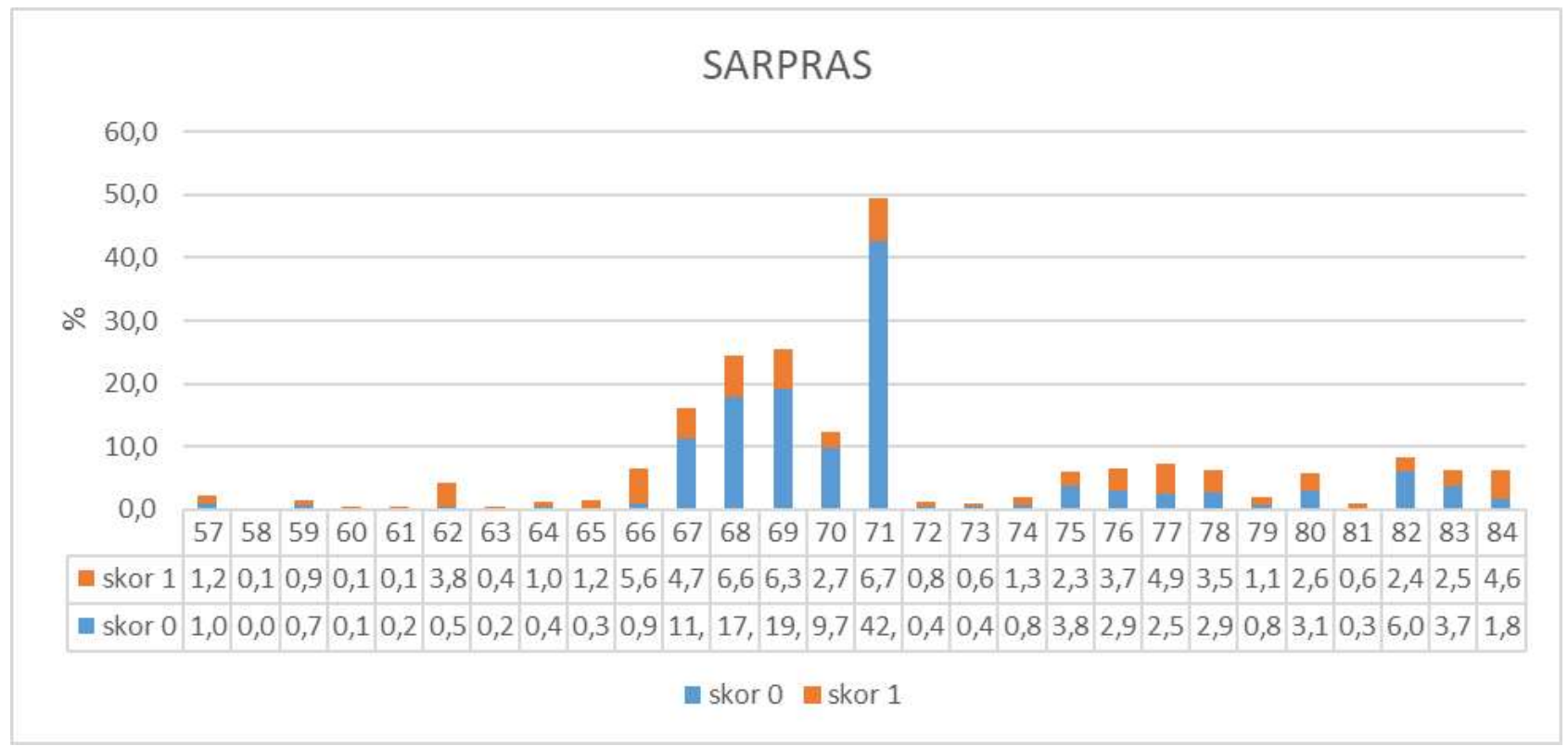

Grafik 3 Standar Sarana dan Prasarana 
belum memiliki ruang komputer atau Teknologi Informasi dan Komunikasi (TIK) secara memadai; butir 71: sekolah belum memiliki ruang laboratorium bahasa.

Dari hasil analisis butir di atas, standar yang dirasakan sulit dipenuhi ada dua, yaitu 1) Standar pendidik dan tenaga kependidikan, 2) Standar Sarana dan Prasarana. Pada standar PTK komponen yang sulit untuk dipenuhi pada satuan pendidikan adalah ketersediaan tenaga kependidikan yakni tenaga administrasi, laboran, dan pustakawan. Tenaga kependidikan ini yang berpengaruh pada perolehan akreditasi standar PTK rendah. Standar sarana dan prasarana juga pada kategori sulit dipenuhi pada sebagian besar sekolah karena tidak memiliki sarana laboratorium dan perpustakaan yang sesuai standar. Standar Kompetensi Lulusan, Standar Isi, Standar proses, Standar Penilaian, Standar Pengelolaan dan Standar Pembiayaan tidak ada yang jawaban D dan E lebih dari 10\%. Artinya dari enam standar tersebut sebagian sekolah tidak ada masalah.

Dalam implementasi SNP berdasarkan data dan informasi yang diperoleh dari kepala sekolah, pengawas sekolah, dan Cabang Dinas Pendidikan Menengah dapat diuraikan sebagai berikut.

\section{Standar Kompetensi Lulusan}

Pencapaian standar kompetensi lulusan bagi guru masih adanya kendala dalam kemampuannya untuk menjelaskan kepada siswa tentang fakta, prosedur, konsep, dan metakognitif. Guru belum semua sama dalam memahami aplikasi metakognitif di kelas. Sebagian guru juga mengalami kesulitan dalam mengajarkan materi pembelajaran yang sesuai dengan tuntutan kurikulum. Kendala lain yaitu terkait dengan penilaian sikap dan karakteritik siswa. Kurikulum sudah berlangsung cukup lama, tetapi guru masih sulit melaksanakan tupoksinya dalam melakukan perencanaan, pelaksanaan, dan evaluasi pembelajaran. Penilaian sikap dan karakter memerlukan instrumen yang sederhana dan mewakili aspek yang dinilai. Oleh karena itu, jurnal sebagai instrumen utama harus disiapkan di setiap kegiatan pembelajaran. Dalam konteks peningkatan kompetensi guru, sekolah maupun dinas pendidikan tingkat provinsi perlu mengidentifikasi seberapa banyak jumlah guru yang belum terampil dan yang sudah terampil. Untuk itu perlu kebijakan terintegrasi antara dinas pendidikan provinsi, balai pendidikan menengah, pengawas sekolah, dan kepala sekolah. Dinas pendidikan provinsi sebagai sumber kebijakan dan balai pendidikan menengah, pengawas sekolah, dan kepala sekolah sebagai sasaran kebijakan. Subjek kebijakan adalah pemberdayaan guru agar sesuai dengan harapan yakni dapat melampaui SNP yang diharapkan. Dengan demikian, berdampak pada kemampuan dalam memberikan standar pelayanan yang baik yakni di atas standar pelayanan minimal.

\section{Standar Isi}

Standar isi menunjukkan sebagian guru masih menganggap bahwa perangkat pembelajaran yang dibuat belum dianggap penting dan hanyalah sebagai persyaratan administrasi dalam pembelajaran sehingga tampak pengembangannya belum optimal. Pemahaman guru terhadap standar isi juga belum merata sehingga masih ada beberapa guru yang malas untuk membuat/menyusun perangkat pembelajaran secara mandiri. Kendala lain terkait implementasi standar isi yaitu pelaksanaan proses belajar, pengerjaan perangkat pembelajaran yang menyita waktu, ketersediaan sarana, karakteristik siswa yang beragam, pembelajaran lintas peminatan yang memberikan kendala dalam pelaksanaan proses belajar di dalam kelas. Kemampuan guru yang belum sama dalam melayani proses pembelajaran dengan standar isi yang sama perlu mendapat perhatian serius dari berbagai pihak, baik sekolah maupun pemerintah daerah. Keterbatasan media 
pembelajaran misalnya, perlu usaha nyata dalam pengadaannya dengan melibatkan sekolah dan guru, serta pemerintah daerah dan dinas. Selama ini, ketercukupan sarana pembelajaran alat dan media selalu menjadi alasan bagi sekolah dan guru ketika hasil pembelajaran belum optimal. Oleh karena itu, perlu keterlibatan langsung pemerintah daerah melalui program pemberdayaan sekolah dalam pemenuhan alat dan media pembelajaran. Jika ketersediaan alat dan media pembelajaran tercukupi, tidak ada alasan bagi sekolah dan guru ketika pembelajaran belum optimal. Dalam konteks kegiatan pembelajaran, standar isi sangat penting sehingga perlu diusahakan oleh berbagai pihak agar kendala yang dialami guru bisa diminimalisir. Sehingga akan berkontribusi pada pencapaian SNP.

\section{Standar Proses}

Dalam standar proses, sebagian guru belum menyusun silabus. Guru tidak seluruhnya terampil dan dapat melakukan pembelajaran dengan jawaban yang kebenarannya multidimensi. Kesulitan lain yang dihadapi guru yaitu tidak dapat melakukan kegiatan pembelajaran menuju keterampilan aplikatif. Kendala dalam pelaksanaan standar proses yaitu keterbatasan kepala sekolah untuk mensupervisi karena padatnya kegiatan internal dan eksternal serta kekurangan sarana belajar. Dalam hal ini, perlu pembinaan secara berkelanjutan terhadap kepala sekolah. Dinas pendidikan perlu melakukan evaluasi kinerja akademik kepala sekolah agar hal-hal substantif dapat terekam dengan baik. Masalah tidak sempatnya kepala sekolah melakukan supervisi terhadap guru dalam melaksanakan pembelajaran di kelas merupakan masalah yang serius mengingat tugas utama kepala sekolah salah satunya adalah melaksanakan kegiatan supervisi terhadap pembelajaran yang dilakukan oleh guru. Ketika teridentifikasi bahwa guru membuat silabus dan Rencana Pelaksanaan Pembelajaran
(RPP) hanya ketika ada pengawas sekolah yang datang dan melakukan supervise. Fenomena ini sangat memprihatinkan karena pengembangan silabus merupakan tugas guru dalam merencanakan kegiatan pembelajaran sehingga proses akan berlangsung dengan baik dan sesuai dengan SNP. Dalam melaksanakan evaluasi kinerja akademik kepala sekolah diperlukan laporan kinerja kepala sekolah yang dapat memetakan kinerjanya. Pada bidang apa kepala sekolah belum menunjukkan kinerjanya secara optimal. Jika kegiatan pembelajaran yang dilakukan oleh guru masih minim, pengawas sekolah dapat melakukan pembinaan kepada kepala sekolah dalam hal pentingnya melaksanakan kegiatan supervisi kegiatan pembelajaran di kelas.

\section{Standar Penilaian}

Pada standar penilaian, masih ada guru yang kurang tertib dalam melakukan pelaporan penilaian secara periodik. Masih banyak guru dalam melakukan penilaian tidak sesuai dengan aturan atau kaidah yang berlaku. Pola komunikasi dan pelaporan hasil penilaian yang belum optimal seringkali ada beberapa masalah kesulitan belajar siswa dan penyimpangan perilaku siswa yang terlambat diidentifikasi dan ditangani. Artinya bahwa kompetensi guru masih bermasalah dalam melakukan proses penilaian terhadap pelaksanaan proses belajar-mengajar. Dalam hal ini, perlu kegiatan mengidentifikasi permasalahan terhadap kompetensi guru dalam melaksanakan penilaian pembelajaran di kelas. Permasalahan bisa pada kompetensi guru, instrumen yang terlalu banyak, atau kebijakan pengawasan yang masih lemah. Pada dasarnya, guru lulus dari program strata satu merepresentasikan kecakapan guru dalam melaksanakan kegiatan pembelajaran termasuk melaksanakan kegiatan penilaian yang standar. Jika masalahnya guru, maka perlu kegiatan pelatihan secara berkelanjutan dalam melaksanakan kegiatan penilaian yang standar. 
Jika masalahnya adalah kurang lenturnya pengawas sekolah dalam mengembangkan perangkat penilaian, maka perlu ada kebijakan terhadap guru dalam melaksanakan kegiatan penilaian pembelajaran. Sebagai contoh, perlu dikembangkan instrumen yang sederhana agar guru dapat menilai siswa dari semua aspek. Dengan instrumen yang ada selama ini, sudah diyakini bahwa guru tidak memiliki waktu yang cukup untuk melaksanakan penilaian apalagi melakukan pengolahan hasil penilaian di rumah. Diperlukan insentif yang memadai dari pemerintah daerah terhadap hal ini baik berupa kegiatan yang memberikan kelonggaran terhadap guru dalam mengembangkan perangkat penilaian, atau ada kebijakan lain yang strategis untuk hal tersebut. Perlu optimalisasi peran pengawas dan kepala sekolah dalam mendorong dan membina guru untuk tertib administrasi termasuk administrasi penilaian terhadap kompetensi siswa baik menyangkut kecakapan spiritual, sosial, pengetahuan, dan keterampilan siswa.

\section{Standar Pendidik dan Kependidikan}

Untuk Standar Pendidik dan Tenaga Kependidikan, kendala yang dihadapi adalah masih ada guru yang belum tersertifikasi. Sebagian besar sekolah tidak memiliki tenaga administrasi, tenaga laboran, dan tenaga pustakawan. Walaupun sudah terakreditasi A sebagian besar sekolah sampel masih terkendala dengan kepemilikan tenaga tersebut. Masalah guru yang belum memiliki sertifikat pendidik adalah wilayah pemerintah pusat dan daerah. Pemerintah pusat diwakili oleh kementerian pendidikan dan kebudayaan yang dalam hal ini adalah Direktorat Jenderal Pendidik dan Tenaga Kependidikan yang harus serius dalam menyelesaikan masalah ini. Kuota harus semakin ditingkatkan agar proses sertifikasi bisa berlangsung lebih cepat. Oleh karena itu, penerimaan guru baru harus sudah memiliki sertifikat pendidik. Jika menerima guru baru yang belum memiliki sertifikat, hanya akan memperpanjang proyek sertifikasi yang tidak berkesudahan. Dengan demikian, perguruan tinggi perlu segera menyelenggarakan Pendidikan Profesi Guru (PPG) prajabatan atau PPG mandiri agar ketersediaan calon guru yang memiliki sertifikat pendidik bisa mengisi kekosongan formasi. Percepatan PPG harus menjadi prioritas agar segera menyelesaikan permasalahan yang terus mewarnai sistem pendidikan di tanah air. Sementara untuk masalah keberadaan tenaga laboran, teknisi, dan pustakawan yang belum terstandar adalah melalui pelatihan bagi yang sudah ada dan rekrutmen tenaga baru dengan persyaratan ketat sesuai dengan kebutuhan. Sebagai contoh, ketika mayoritas sekolah belum memiliki tenaga pustakawan yang tersertifikasi, perlu rekrutmen tenaga pustakawan yang memiliki latar belakang pendidikan ilmu perpustakaan. Pustakawan merupakan sebuah profesi yang termasuk dalam jabatan fungsional puatakawan. Untuk hal ini perlu diakui bahwa hampir setiap sekolah belum memiliki pustakawan yang profesional. Pemerintah daerah dalam hal ini dinas pendidikan provinsi perlu memikirkan tentang kondisi ini.

\section{Standar Sarana dan Prasarana}

Walaupun sudah terakreditasi A sebagian besar sekolah sampel belum memiliki sarana dan prasarana sesuai standar. Kendala yang dihadapi standar sarana dan prasarana, yaitu sebagian besar sekolah belum memiliki laboratorium (Fisika, Kimia, Biologi, Komputer dan Bahasa) maupun perpustakaan yang sesuai standar. Hal yang paling memprihatinkan adalah hampir semua sekolah belum memiliki laboratorium IPS. Pada umumnya sekolah fokus pada pengadaan laboratorium IPA sehingga untuk IPS sangat terabaikan. Permasalahan sosial terus saja muncul mengingat perhatian pemerintah, pemerintah daerah, dinas pedidikan terhadap pembelajaran IPS masih sangat minim. Minimnya sarana dan prasarana berkorelasi positif 
terhadap rendahnya kegiatan pembelajaran. Oleh karena itu berdampak pula terhadap rendahnya luaran pembelajaran yang kurang berkualitas. Masalah kurangnya sarana dan prasarana pembelajaran seharusnya sudah selesai dalam waktu lima tahun seorang kepala sekolah menjabat. Jika hal ini terus mewarnai permasalahan di sekolah, dapat dipertanyakan apa saja tugas kepala sekolah dalam memimpin sebuah satuan pendidikan. Fenomena ini harus menjadi perhatian serius bagi pemerintah, pemerintah daerah, dinas pendidikan, dan semua stake holder agar masalah ini tidak terus berkepanjangan. Perlu ada kebijakan selama setahun program yang difokuskan terhadap pengadaan sarana dan prasarana. Pemerintah harus konsisten jika ingin luaran pendidikan berkualitas. Sarana dan prasarana harus diperhatikan dan perlu kebijakan yang serius dalam menyelesaikan masalah ini. Bantuan langsung dan hibah adalah sebuah program yang perlu menjadi fokus kebijakan dari pemerintah daerah. Jika APBN kesulitan dalam pengadaan ini, APBD harus fokus terhadap pengadaan sarana dan prasarana yang memadai.

\section{Standar Pengelolaan}

Kendala standar pengelolaan yang dihadapi sebagian sekolah adalah belum memiliki sistem informasi yang terbaik sesuai dengan perkembangan teknologi dan keterbatasan SDM yang ada. Sebagian sekolah masih ada kendala dalam melibatkan pemangku kepentingan dalam penyusunan rencana program sekolah dan kepala sekolah belum memiliki wawasan kewirausahaan dalam mengelola sekolah. Untuk pengelolaan sekolah, kebijakan harus fokus pada peningkatan kemampuan manajerial kepala sekolah baik manajerial yang mencangkup sumber daya maupun kewirausahaan. Usaha peningkatan kemampuan manajerial merupakan wilayah binaan pengawas sekolah. Salah satu komponen penting dalam usaha pembinaan kepala sekolah adalah perlunya kegiatan pembinaan yang tepat sasaran. Untuk menemukan rekomendasi kebijakan pembinaan yang baik dapat dihasilkan dari evaluasi kinerja manajerial kepala sekolah. Hasil evaluasi kinerja manajerial kepala sekolah harus melahirkan alternatif rekomendasi terhadap hasil evaluasi kinerja. Selama ini hasil Penilaian Kinerja Kepala Sekolah (PKKS) tidak melahirkan rekomendasi nyata bagi pengawas maupun kepala sekolah. Kepala sekolah bahkan tidak tahu kinerja bagian mana saja yang belum optimal. Hal ini dikarenakan hasil PKKS bersifat tertutup dan hanya menjadi referensi bagi Dinas Pendidikan Provinsi yang tidak dipublikasikan. Oleh karena itu sebaiknya ke depan hasil evaluasi kinerja kepala sekolah harus terbuka sehingga kepala sekolah mengetahui mana saja kelemahan yang harus diperbaiki, mana saja yang harus ditingkatkan. Demikian pula dengan pengawas sekolah dapat menyusun alternatif dalam membuat program pembinaan kepala sekolah secara berkelanjutan. Dengan demikian maka standar pengelolaan yang dirasa belum optimal akan menjadi lebih terencana dan terlaksana dengan baik. Oleh karena itu diperlukan program yang terukur baik itu program dari dinas pendidikan provonsi, balai dikmen, maupun pengawas, dan bahkan kepala sekolah itu sendiri dalam mengembangkan standar pengelolaan. Pada gilirannya akan tercapai pula standar nasional pendidikan yang diharapkan.

\section{Standar Pembiayaan}

Kendala yang ditemui pada standar pembiayaan yaitu sebagian sekolah mengalami keterbatasan biaya operasional untuk melakukan inovasi peningkatan mutu. Kendala lain yaitu laporan yang diakses oleh pemangku kepentingan tidak tepat waktu. Hal ini dikarenakan pencairan dana ke dalam rekening sekolah tidak tepat waktu/ melewati rentang waktu tertentu dan perubahan atau penataan sistem yang setiap tahun diperbarui. Terkait dengan permasalahan ini, perlu kebijakan yang progresif terhadap pemenuhan standar pembiayaan pendidikan. 
Jika dengan program BOS dan BOSDA masih belum memenuhi aspek standar pembiayaan, pelibatan masyarakat merupakan alternatif yang dapat diambil sebagai sebuah kebijakan pemerintah daerah maupun pusat. Pelibatan masyarakat dalam sebuah komite belum optimal, secara terpadu merupakan salah satu alternatif. Oleh karena itu, BOS perlu dikaji ulang efektivitas dan efisiensinya dalam peningkatan mutu pendidikan. Pemerintah pusat dan pemerintah daerah perlu melakukan perencanaan yang matang dalam merencanakan dan melaksanakan program BOS melalui model yang lebih oriented agar tepat sasaran dan menghasilkan luaran pendidikan yang bermutu dan bermartabat.

Dari hasil implementasi SNP seperti di atas menunjukkan bahwa sekolah masih mengalami kesulitan dalam pemenuhan SNP. Kesulitan yang dihadapi yaitu pada segi a) Keterbacaan bahwa sebagian kepala sekolah dan guru masih belum semuanya memahami SNP dengan baik. Kepala sekolah dan guru masih mengalami kesulitan dan kendala dalam implementasi karena standar yang masih dirasa rumit dan menjelimet; b) Keterlaksanaan yang belum optimal karena kesulitan dalam pemenuhan standar pada tingkat satuan pendidikan. Standar yang dirasakan sulit dipenuhi yaitu standar PTK, standar sarana dan prasarana, dan standar pembiayaan. Terkait dengan tiga standar tersebut sekolah bersifat menerima saja sehingga pemenuhan standar bergantung kuota yang diberikan oleh pemerintah; c) Ketercapaian, masih belum semua standar bisa dicapai sekolah yang berstatus negeri. Namun bagi sekolah swasta berkategori swasta mandiri dengan pembiayaan yang cukup, SNP dapat dicapai dengan baik. Sekolah swasta dengan pembiayaan mandiri dapat mendanai keperluannya dalam mencapai standar tersebut. Oleh karena itu, pemerintah daerah perlu merespon hambatan pendanaan sekolah sehingga mencapai standar nasional pendidikan.

\section{Pembahasan}

Berdasarkan hasil penelitian lapangan, ditemukan beberapa hambatan dalam pencapaian standar isi yakni mencakup tenaga pendidik bahwa: 1) sebagian besar guru menganggap bahwa perangkat pembelajaran yang dibuat hanyalah formalitas pemenuhan kebutuhan administrasi belaka, 2) masih ada beberapa guru yang tidak membuat/menyusun silabus perangkat pembelajaran secara mandiri, 3) masih ada guru yang menyusun perangkat tidak berdasarkan kompetensi. Apabila merujuk pada pendapat Sallis (2002), bahwa sekolah dikategorikan bermutu apabila memiliki indikator sebagai sekolah berfokus pada pelanggan, baik pelanggan internal maupun eksternal. Sekolah berfokus pada upaya untuk mencegah masalah yang muncul. Hal ini bermakna ada komitmen untuk bekerja secara benar dari awal. Sekolah berinvestasi pada sumber daya manusia dan harus memiliki strategi untuk mencapai kualitas, baik di tingkat pimpinan, tenaga akademik, maupun tenaga administratif. Oleh karena itu pendapat ini memerlukan respon dalam usahausaha untuk mengatasi kendala-kendala yang dihadapi. Guru harus mengoptimalkan kinerjanya dalam merencanakan, melaksanakan, dan juga mengevaluasi kegiatan pembelajaran. Melalui sebuah perencanaan yang baik, akan berdampak pada implementasi yang baik dan akan menunjukkan hasil yang baik pula. Dengan demikian, perlu koordinasi yang baik antara kepala sekolah, wakil kepala sekolah, guru, dan tenaga kependidikan dalam membuat sebuah format sekolah unggul dan bermutu. Hasil yang melampaui SNP adalah keniscayaan jika semua kendala yang dihadapi diidentifikasi dan dipecahkan solusinya secara sistemis dan sistematis melalui sebuah kebijakan yang populis dan berpihak pada usaha-usaha peningkatan mutu pendidikan secara berkelanjutan.

Kendala yang terkait dengan pelaksanaaan proses belajar terhadap implementasi SNP yang 
dihadapi yaitu: 1) terkadang apa yang dilaksanakan di kelas tidak sesuai dengan perencanaan, 2) sekolah mengatur beban belajar berdasarkan bentuk pendalaman materi, 3) sulit mengatur beban belajar berdasarkan bentuk pendalaman materi karena terbentur dengan Aplikasi Dapodik, 4) pelaksanaan pembelajaran di luar jam KBM umum kurang efektif.

Kendala terkait waktu terhadap implementasi SNP yang dihadapi paling dominan adalah: 1) pengerjaan perangkat pembelajaran yang menyita waktu sehingga menghabiskan waktu tugas pokok dan 2) pengaturan antara waktu beban mengajar dan waktu untuk menganalisis perangkat pembelajaran serta tenggang waktu pengumpulan perangkat yang sangat terbatas.

Pada prinsipnya penentuan mutu pendidikan harus memiliki standar tertentu sebagai acuan yang akan dicapai. Oleh karena itu, standar yang ditentukan harus memberikan jaminan bagi pelanggan untuk mendapat layanan yang berkualitas. Hambatan-hambatan akan teratasi dengan penentuan standar sekolah terlebih dahulu.

Hambatan yang terkait sarana dan prasarana terhadap implementasi yang dihadapi yaitu: 1) ketersediaan alat-alat praktik yang hanya bersifat umum; alat-alat praktik untuk keterampilan khusus tidak ada (menimbang, mengukur, membaca skala) dan, 2) faktor kecukupan ruang kelas dan ruang guru masih kurang.

Hambatan yang terkait dengan siswa terhadap implementasi yang dihadapi adalah: 1) pengembangan diri siswa yang sangat beragam sulit untuk diterapkan pada semua siswa, 2) dalam penyusunan perangkat pembelajaran yang disesuaikan dengan tingkat kompetensi siswa terkendala sumber daya manusia (SDM) dan tingkat kompetensi siswa yang beragam dan bervariatif terutama pada kompetensi pengetahuan dan keterampilan. Sehubungan dengan hal tersebut sekolah hanya membuka kelas regular dalam pelaksanaan Penerimaan Peserta Didik Baru (PPDB). Sekolah hanya menerapkan seleksi melalui wawancara dan tidak mengadakan seleksi secara akademik (berdasarkan passing grade hasil UN di SMP maupun tes akademik bagi calon peserta didik), 3) sulit membedakan antara kompetensi pengetahuan, keterampilan terutama pada mata pelajaran tertentu misalnya matematika. Kendala yang lain yaitu kurangnya dukungan pemangku kepentingan, penerapan kurikulum muatan lokal, sistem peminatan, dan Sistem Satuan Semester (SKS).

Berdasarkan hasil penelitian hambatan tenaga pendidik terhadap implementasi standar proses adalah: 1) SDM sekolah yang tidak memadai dan penyelenggaraan pelatihan yang minim; 2) tidak semua guru dapat melakukan pembelajaran dengan jawaban yang kebenarannya multidimensi; 3) tidak seluruh guru dapat melakukan pembelajaran menuju keterampilan aplikatif; 4) memberikan pemahaman kesadaran pemberdayaan siswa sebagai pembelajar sepanjang hayat; 5) tidak semua guru melakukan penilaian otentik pada level kognitif 4, 5 dan 6; 6) sebagian besar guru menganggap perangkat pembelajaran yang dibuat hanyalah formalitas pemenuhan kebutuhan administrasi, guru tidak membuat RPP sendiri, minat baca dan daya baca yang masih rendah, 7) masih ada beberapa guru yang belum dapat melakukan pengawasan dan penilaian otentik dalam proses pembelajaran. Hambatan lain adalah terkait dengan alokasi waktu yang dianggap sangat terbatas, supervisi yang belum maksimal, dukungan sarana dan prasarana, kompetensi melaksanakan penilaian otentik, dan mata pelajaran yang kebenarannya multidimensi atau bersifat nisbi (Rusman, 2015)

Hambatan kemampuan tenaga pendidik terhadap implementasi standar penilaian yang dihadapi adalah: 1) konsep tentang penilaian pada pendidik di sekolah belum merata. Mereka belum variatif dalam melakukan penilaian 
terhadap peserta didik, 2) belum semua guru melengkapi perangkat teknik penilaian, 3) guru belum terlatih menyusun rubrik penilaian secara mandiri untuk ramah sikap dan keterampilan, 4) banyaknya aspek yang harus dinilai membuat guru kurang tertib dalam melakukan pelaporan penilaian secara periodik, 5) masih banyak guru dalam melakukan penilaian tidak sesuai dengan aturan atau kaidah yang berlaku, misalnya guru melakukan penilaian hanya dari nilai ulangan harian tanpa melakukan penilaian proses dalam kegiatan belajar-mengajar. Selain itu, pola komunikasi dan pelaporan hasil penilaian belum optimal karena seringkali ada beberapa masalah kesulitan belajar siswa dan penyimpangan perilaku siswa yang terlambat dideteksi dan ditangani, 6) guru kesulitan membagi waktu antara tugas pokok dan tindak lanjut penilaian, 7) kemampuan menilai sikap siswa yang sangat abstrak karena sebatas konasi atau kecenderungan bertindak baik melalui onservasi maupun angket, 8) kemampuan guru yang terkait dengan penyusunan instrumen penilaian.

Hambatan dalam pemenuhan standar pendidik dan tenaga kependidikan terhadap implementasi SNP yang dihadapi adalah: 1) tidak tersedianya guru untuk setiap mata pelajaran seperti sejarah dan sosiologi, 2) belum semua tenaga guru dan kependidikan bersertifikat, 3) belum semua guru melengkapi perangkat teknik penilaian, 4) belum semua pendidik dan tenaga kependidikan yang diperlukan sekolah sesuai dengan ketentuan syarat yang seharusnya, 5) keterbatasan jumlah SDM dan kompetensi SDM, 7) untuk Indikator 1 , subindikator 2, ada beberapa guru yang mengajar bidang mata pelajaran tertentu $>24$ jam pelajaran, 8) beberapa tenaga pendidik yang masih berstatus non-PNS belum memiliki sertifikat pendidik karena belum mengikuti Pendidikan dan Latihan Profesi Guru (PLPG) atau Pendidikan Profesi Guru (PPG).

Era revolusi industri 4.0 yang mensyaratkan kompetensi berbasis teknologi informasi dan komunikasi tentu mendorong untuk upgrading kompetensi tenaga pendidik dan tenaga kependidikan yang ada. Pelayanan kependidikan dapat semakin ditingkatkan untuk dapat mengikuti perkembangan zaman. Dalam upaya meningkatkan kompetensi, diperlukan programprogram yang berdampak pada pembiayaan program dan ketersediaan sarana prasarana dan fasilitas pendukung lainnya. Guru harus memiliki kemampuan utuh dalam melakukan penilaian otentik (Azim \& Khan, 2012; Rourke \& Coleman, 2011).

Untuk dapat memenuhi tuntutan pembelajaran dengan berpusat kepada peserta didik yakni pembelajaran yang mendorong motivasi, minat, kreativitas, inisiatif, inspirasi, kemandirian, dan semangat belajar peserta didik, guru dituntut untuk dapat memilih strategi pembelajaran bervariasi sesuai tuntutan materi pembelajaran. Nurfaisal (2017) menyatakan guru kesulitan dalam mengimplementasikan usaha pemenuhan tuntutan standar proses dalam pembelajaran. Pembelajaran cendrung berjalan secara konvensional. Faktor yang memengaruhi antara lain disebabkan media dan peralatan pembelajaran yang minim di sekolah, jumlah siswa yang terlalu besar dalam satu kelas, sehingga tidak mendukung diterapkannya pembelajaran yang aktif dan kreatif yang berpusat kepada siswa. Pendekatan pembelajaran yang terjadi lebih sering berpusat pada guru (teacher-centred approaches). Profesionalitas guru sangat penting untuk meningkatkan mutu pendidikan (Admiraal, Janssen, Huizenga, Kranenburg, Taconis, \& Corda, (2014); Frey, Schmitt, \& Allen, 2012).

Permasalahan guru di Indonesia sangat beragam, jika dikelompokkan berdasarkan empat kompetensi guru antara lain: 1) kompetensi profesional: kecakapan guru dalam menyiapkan perangkat pembelajaran; kecakapan guru menentukan dan menyajikan materi esensial; masih mengandalkan LKS yang dijual di pasaran, belum membuat bahan ajar sendiri; sains 
disajikan secara teoretis, belum menggunakan laboratorium secara optimal, 2) kompetensi pedagogik: strategi yang digunakan kurang tepat; gaya mengajar yang kurang menyenangkan peserta didik; peran sebagai pendidik, pengajar, dan pelatih belum optimal; tugas yang terlalu padat kepada peserta didik, 3) kompetensi sosial/interpersonal: kurang terbuka terhadap kritikan teman sejawat, 4) kompetensi personal/individu: afeksi guru belum bisa diteladani, kurang menerapkan disiplin bagi anak didik; komitmen, kinerja, dan keiklasan dalam merencanakan dan melaksanakan pembelajaran masih kurang.

Hambatan dalam implementasi standar sarana dan prasarana yang dihadapi yaitu: 1) kendala dana untuk pengadaan/melengkapi sarana dan prasarana belajar yang layak, 2) sekolah tidak mampu membeli secara keseluruhan sarana belajar, 3) keterbatasan dana untuk lokasi parkir dan kantin yang sehat, 4) hampir semua indikator sudah tersedia namun dari sisi detail teknis seperti ukuran luas dan kelengkapan sarana penunjang belum sepenuhnya terpenuhi, sehingga diperlukan pengembangan/penambahan luas dan kapasitas serta melengkapi sarana penunjang yang diperlukan. Ruang yang memerlukan pengembangan di antaranya perpustakaan, laboratorium, dan ruang kelas. Keterbatasan dana menjadi kendala dalam pengadaan dan pemeliharaan standar sarana dan prasarana. Hambatan lain adalah ketersediaan Iahan tanah yang terbatas dan kompetensi dalam penggunaan sarana dan prasarana.

Berdasarkan informasi yang diperoleh dari kepala sekolah bahwa hambatan dengan pemangku kepentingan terkait implementasi standar pengelolaan yang dihadapi yaitu: 1) dalam perencanaan pengelolaan sekolah sulit menentukan waktu untuk berkumpul bersama pemangku kepentingan, 2) kesadaran peran orang tua untuk membantu pengangkatan kualitas sekolah dari faktor ekonomi masih rendah. Pendidikan orang tua dan faktor kebijakan politik pemerintah daerah juga berpengaruh (sejak tahun 2017/2018 subsidi dihilangkan). Untuk menambah kesadaran akan peran serta masyarakat/orang tua agak sulit, 3) sulit membangun kemitraan dengan masyarakat dikarenakan mereka beranggapan bahwa sekolah sudah dibiayai oleh pemerintah. Kendala lain adalah sistem informasi yang belum optimal, sumber daya manusia, dan kemampuan kewirausahaan.

Berdasarkan informasi yang diperoleh dari kepala sekolah bahwa kendala biaya operasional terhadap implementasi standar pembiayaan yang dihadapi yaitu: 1) beban biaya operasional jika hanya sesuai dengan ketentuan akan sulit untuk melakukan inovasi, 2) penambahan ruang kelas dan laboratorium di lantai 2 membutuhkan dukungan sumbangan pembinaan pendidikan (SPP) karena bantuan pemerintah hanya untuk 1 lantai, 3) selalu mengalami kekurangan biaya operasional, 4) adanya biaya operasional nonpersonal yang tidak mungkin dibiayai oleh anggaran yang ada, 5) adanya ketidaksinkronan penggunaan anggaran di sekolah dengan juknis peruntukan anggaran dari APBD dan BOS, dan 6) belum tercukupinya beban biaya nonpersonal yang besar karena keterbatasan sumber keuangan sekolah, baik yang bersumber dari APBN/APBD maupun masyarakat. Daftar penerima subsidi silang seringkali bertambah, sehingga pengalokasian dana berubah sesuai dengan ketercukupan dana yang bersumber dari pemerintah (BOS). Hal ini menjadikan tidak sinkron karena alokasi untuk biaya operasional sekolah dihitung dari jumlah siswa yang kurang mampu. Sekolah tidak mengeluarkan kebijakan dalam melaksanakan subsidi silang untuk membantu siswa kurang mampu. Dengan pertimbangan bahwa pemerintah telah mengeluarkan kebijakan untuk membantu peserta didik yang kurang mampu sesuai dengan ketentuan yang berlaku sehingga bantuan yang diberikan bisa tepat sasaran. Peserta didik dan 
orang tua adalah pelanggan sekolah. Oleh karena itu menurut Sallis (2002), sekolah dikategorikan bermutu apabila sekolah memiliki indikator fokus pada pelanggan, baik pelanggan internal maupun eksternal.

\section{SIMPULAN DAN SARAN}

\section{Simpulan}

Pada jenjang SMA berdasarkan akreditasi 2017 pada umumnya SNP telah melampaui standar. Pencapaian paling tinggi ke paling rendah secara berurutan adalah standar pembiayaan, standar isi, standar penilaian, standar pengelolaan, standar proses, standar kompetensi lulusan, standar sarana dan prasarana, dan standar pendidik dan tenaga kependidikan. Terdapat tiga SNP yang capaiannya paling rendah yakni standar kompetensi lulusan, standar sarana prasarana, dan standar pendidik dan tenaga kependidikan.

Pada tingkat satuan pendidikan standar yang dirasakan sulit dipenuhi yaitu standar pendidik dan tenaga kependidikan, standar sarana dan prasarana, dan standar pembiayaan. Belum semua standar bisa dicapai oleh sekolah negeri. Sekolah swasta yang berkategori mandiri dengan pembiayaan yang cukup SNP dapat dicapai dengan baik. Hal ini karena sekolah swasta dengan pembiayaan mandiri dapat mendanai keperluan untuk mencapai standar tersebut.

\section{Saran}

1. Upaya pencapaian standar nasional pendidikan perlu ada pembinaan sekolah dan kepala sekolah secara berkelanjutan dengan mengacu pada capaian sebelumnya dengan peta akreditasi sekolah. Hasil akreditasi memetakan bagian yang masih perlu mendapat perhatian serius, perlu diprioritaskan sehingga lahir sebuah program yang berkualitas dalam rangka meningkatkan mutu pendidikan secara berkelanjutan.

2. Dalam pemenuhan SNP perlu diklasifikasikan dalam pembagian tanggun jawab. Pada tingkat satuan pendidikan, kepala sekolah bertanggung jawab terhadap ketercapaian standar kompetensi lulusan, standar isi, standar proses, standar penilaian, dan standar pengelolan. Untuk pemenuhan standar pendidik dan tenaga kependidikan, standar sarana dan prasarana, dan standar pembiayaan yang bertanggung jawab untuk melakukan pemenuhan adalah pihak pemerintah pusat atau pemerintah daerah melalui kebijakan pembiayaan pendidikan.

3. Perlu pelibatan semua komponen sekolah antara lain kepala sekolah, wakil kepala sekolah, guru dan tenaga kependidikan untuk mengidentifikasi kelemahankelemahan agar menjadi kekuatan dalam pencapaian standar nasional pendidikan.

\section{PUSTAKA ACUAN}

Admiraal, W., Janssen , T., Huizenga, J. Kranenburg , F., Taconis, R. \& Corda, A. (2014). Eassessment of student-teachers' competence as new teachers. TOJET: The Turkish Online Journal of Educational Technology, 13 (4), 21-29.

Azim, S. \& Khan, M. (2012). Authentic assessment: an instructional tool to enhance students learning. Academic Research International, 2 (3), 314-320.

Akpan, CP. \& Ita, A.A. (2015). Teacher professional development and quality universal basic education in Lagos State, Nigeria. Global Journal of Arts, Humanities and Social Sciences, $3(9), 65-76$.

Alba, C. (2011). Strategi peningkatan mutu pendidikan di perguruan tinggi. Jurnal Sosioteknologi, 10(24),1184-1190.

Celik, S. (2011). Characteristics and competencies for teacher educators: Addressing the need 
for Improved Professional Standards in Turkey. Australian Journal of Teacher Education, 36(4), 18-32. http://dx.doi.org/10.14221/ajte.2011v36n4.3

Devi, V., Devan, D., Soon, P. C., \& Han, W. P. (2012). Comparison of self-directed learning readiness among students experiencing hybrid and traditional curriculum. Journal of Clinical and Diagnostic Research. 6(6), 1047-1050.

Frey, B.B., Schmitt, V.L. \& Allen, J.P. (2012). Defining authentic classroom assessment. Practical Assessment, Research \& Evaluation. 17(2), 215-232.

Jaedun, A., Hariyanto, L., \& Nuryadin, E.R. (2014). An evaluation of the implementation of Curriculum 2013 at the building construction department of vocational high schoos in Yogyakarta. Journal of Education, 7(1), 14-22

Kalolo, J.F. (2015). The quest for quality science education experiences in tanzanian secondary schools. Journal of Studies in Education. 5 (2), 22-39, DOI:http://dx.doi.org/ 10.5296/ jse.v5 i2.7146.

Lee, Y.M., Mann, K.V. \& Frank, B.W. (2010). What drives students' self-directed learning in a hybrid PBL curriculum. Advances in Health Sciences Education. 15(3), 425-437.

McBer, H. (2000). Research into teacher effectiveness: A model of teacher effectiveness. Nottingham: Department for Education and Employment

Nurfaisal. (2017). Usaha-usaha manajerial dalam pencapaian Standar Nasional Pendidikan. Jurnal Manjemen Pendidikan, 12(1), 23-37.

Republik Indonesia. (2003). Undang-Undang Nomor 20 Tahun 2003 tentang Sistem Pendidikan Nasional. Jakarta: Lembaran Negara.

Republik Indonesia. (2005). Peraturan Pemerintah Nomor 19 Tahun 2005 tentang Standar Nasional Pendidikan. Jakarta: Sekretariat Negara.

Rusman. (2015). Curriculum implementation at elementary schools a study on "Best Practices" done by elementary school teachers in planning, implementing, and evaluating the curriculum. Journal of Education and Practice, 6(21), 106-112.

Rourke, A.J. \& Coleman, K.S. (2011). Authentic assessment in e-learning: Reflective and Collaborative writing in the arts. Proceedings Ascilite 2011. Hobart: Concise Paper.

Raharjo, S.B. (2012). Evaluasi trend kualitas pendidikan di Indonesia. Jurnal Penelitian dan Evaluasi Pendidikan, 16(2), 511-532.

Sallis, E. (2002). Manajemen mutu pendidikan (terj. Ahmad Ali Riyadi dan Fahrurrozi, 2006), Yogyakarta: IRCISOD.

Scholtz, A. (2007). An analysis of the impact of an authentic assessment strategy on student performance in a technology-mediated constructivist classroom: a study revisited. International Journal of Education and Development using ICT, 3(4), 42-53. Open Campus, The University of the West Indies, West Indies. Retrieved November 14, 2019 from https://www.learntechlib.org/p/42221/. 